\title{
MEMORY IN DIASPORA
}

MOBOLU CORER

University of Toronto

\section{ARTIST STATEMENT}

The pieces that follow are my interpretation of the voices of two women (one fictional, one real) of Caribbean descent who, in response to certain traumatic incidents, are forced to confront their understandings of home. I chose to write from the perspective of these particular characters because their experiences mirror some of my own. My parents' ethnic background (and my birthplace) is Nigeria. I came to Canada the year I turned seven, almost 15 years ago. While I have lived in Canada for most of my life, I still grapple with whether or not I consider it home. For the most part, this uncertainty has been driven by my experiences with various identity-based questions and the discourses

\section{While I have lived in Canada for most of my life, I still grapple} with whether or not I consider it home.

that surround them. For example, what it means to be (perceived) Canadian vs. an immigrant, or what it means to be black vs. African (Nigerian). Questions such as "Where are you really from?" always remind me that "foreign" is a presumption that precedes me. Conversely, nativity has been ascribed to the White European population in a way that systematically marginalizes the history and perpetuates the violent erasure of Indigenous communities, a practice that persists to this day. I do not consider Canada my place of origin - a sentiment shared by many Canadians -yet those with a perceived sense of belonging have vastly different experiences from those who do not. I am fortunate enough to have been raised learning about and continuously engaging with my culture, but even that has had its limits. There is a certain tension, what I would call a double-sided alienation, that often comes with being a firstgeneration immigrant, particularly of a racialized background. For me, that means not feeling either Nigerian or Canadian "enough," yet being significantly shaped and socialized by both societies. This is a tension I recognized and wanted to highlight in the stories of the two women mentioned above. Moreover, the continuity between my story and (my representation of) their stories is signified by the framework of memory I adopted in the pieces (i.e., "I had forgotten/I remember"), which is from an earlier poem I wrote about my own experience coming to terms with some of the ways my identity changed after moving to Canada.

The first piece is written from the viewpoint of Mona, the protagonist in The Swinging Bridge, a novel by Ramabai Espinet. Mona is an Indo-Trinidadian woman living in Canada. Her story starts in Trinidad, but ironically, the only two "homes" (Trinidad and Canada) she has ever known have never fully accepted her, while her place of ancestral origins (India) has been mostly foreign to her. As a result of their two-fold displacement, her family is described as living in a double diaspora. This piece explores how tracing the journey back home, in all its nuances, through memories and stories, can be full of pain and loss. This quest is prompted by the discovery that Mona's great-grandmother, Gainder, came to Trinidad as an indentured servant. 
The second piece is told from the viewpoint of Dionne Brand, the subject and author of Land to Light On. Brand

This piece explores how tracing the journey back home, in all its nuances, through memories and stories, can be full of pain and loss.

is a Caribbean-born scholar who becomes disillusioned after discovering that Canada, the place she had always romanticized, is rife with racism and intolerance. My piece asks, "What is home?" by exploring how a sense of belonging is cultivated - through community - in some places and deniedthrough systems of oppression-in others.

Mona and Dionne's stories converge in a number of ways: both are women, born and raised in Trinidad and Tobago, with their departures to Canada taking place in their late teens to early 20s. However, there are also significant differences between them. While Mona is of ethnic Indian descent, Dionne is of ethnic African descent. Similarly, and to reiterate, Mona's story is a fictionalized narrative inspired by the real-life experiences of author Ramabai Espinet, while Dionne's is the autobiographical account of Dionne Brand, a celebrated literary figure in Canada.

I HAD FORGOTTEN: A TALE OF TWO DIASPORAS

I had forgotten seeing myself in crowds

Feeling like a small piece of a

Very brown

And multi-hued picture

I had forgotten the melody

Of my native tongue

The way it dances around the lungs

Thumping drumbeats of ancient practices

I had forgotten the smells

A mixture of earth, spice, and sweat

So pungent it lived in my clothes

I had forgotten the journey here

The first time

Fleeing lands of misogyny

To encounter it

On ships of white supremacy

Carrying hope in small bags

To meet bondage in iron hands 
I had forgotten the ship's fuel:

The insatiable pursuit of independence

Shedding story,

Shedding song,

Shedding proverb,

Shedding love

To still be searching for it oceans away

The second time

Running the race to the land

Of the displaced,

To become a myth made alive

In the image of the fair-skinned

I forgot my skin

Then I remembered it

Like a car accident

It stayed with me long after the smoke cleared

And Muddy had taken on new meaning

I forgot our craftiness

The way we developed amnesia

Turned them into palm-sized relics

Singing hymns and hailing the Queen

All to become a distorted form of respectable

How did my mothers do it?

I asked myself

Make the prisons of their bodies comfortable

Enough to live in,

To breed in

Gathered our Indian

Made a bonfire of it

Let it burn till it filled the lungs of our

ancestors

Kept the ashes

I forgot we put on new faces

A gentrified version of our old ones

In softened tones

To dream dreams in?

I forgot we once had our own songs

The melodic marriage of history and agony

It only ever played in our souls now 
UNSETTLEMENT IN A SETTLED LAND

I remember my first steps out of the airport Seeing enormous sugar flakes

Falling from the sky and melting

I remember it tasted like milk and honey

I remember the first time it became rancid

The police officer still not convinced

Truth and legitimacy could exist in brown

bodies

I had forgotten I chose this

Scraped my elbows

Bruised my lips

To escape the banal hills of home

To get to a white heaven

I forgot my crown

I forgot I used to know I wore a crown

I remember the news

How it painted home with so much void-ness

So much red

I wondered how l'd survived there so long

It wasn't until I returned to all I forgot

That I remembered hands

The hands that stirred pots,

The hands that washed wounds

That dressed them in warmth and spice and eyes

That I realized those that held the paintbrush were never our own

A C K NOW LE D G M E N T S

I'd like to thank my professor Nikoli Attai for providing me the opportunity to find myself in these women and for allowing me to share this piece in a classroom of my peers. l'd also like to thank my family and closest friends for their continued support. Your faith in me has meant more than you'll know.
AUTHOR BIO Mobolu Coker is a fourth-year student at the University of Toronto. She is currently pursuing a degree in the social sciences. She is inspired by diversity, both in human experiences and in nature, and she enjoys creatively finding parallels between the two

R E F E R E N C E S Brand, D. (1997). Land to light on. Toronto: McClelland \& Stewart Limited. Espinet, R. (2003). The Swinging Bridge. Toronto: Harper Perennial Canada. 